\title{
Effect of Vitamin D Supplementation on Ovulation among Women with PCO
}

\author{
AHLAM NASIR ABOUD AL HAYANI, M.D. \\ The Department of Obstetrics and Gynecology, Faculty of Medicine, El Anbar University, Iraq
}

\begin{abstract}
Background: Polycystic Ovarian Syndrome (PCOS) is prevalent worldwide among female endocrine disorder, affecting nearly $5 \%$ to $12 \%$ of child bearing age women. PCOS is considered as the most common cause of an ovulatory infertility and it has clinical symptoms include an ovulation with or without oligo-ovulation, infertility, menstrual irregularity, polycystic ovaries and hyperandrogenism.
\end{abstract}

Aim of Study: This study aim was to explore and compare the effects of Vitamin D supplementation vs. placebo on ovulation in women with PCOS.

Patients and Methods: 400 women with PCOSwere included in this randomized controlled trial. Patients were randomly allocated into 2 groups as follows: Vitamin $\mathrm{D}$ group $(n=200)$ and control group $(n=200)$. Follow-up was done after three months by measuring change vitamin $\mathrm{D}$ level, change in insulin resistance as measured by fasting glucose and fasting insulin ratio, change in testosterone level, and change in free androgen index.

Results: 200 of them allocated to control group. Among 200 women in vitamin D group, 160 women had vitamin D deficiency and the other 40 had normal vitamin D level. FBS, fasting insulin and HOMA-IR were statistically significantly higher in the vitamin D deficient subgroup and the control group compared to the normal vitamin D subgroups; whereas no statistically significant differences were found between the vitamin D deficient subgroup and the control group. No statistically significant differences were found between the three groups in the various components of the lipid profile and hormonal profile. There were statistically significant differences between groups as regards FBS, fasting insulin, HOMA-IR, FAI, Testosterone, TC and LDL-C.

Conclusion: We concluded that vitamin D seems to be a contributing etiopathogenic factor in anovulatory, metabolic and hormonal aberrations in women with PCOS that might have a potential adjuvant role to standard induction of ovulation regimen.

Key Words: PCOS - Ovulation - Vitamin D.

Correspondence to: Dr. Ahlam Nasir Aboud Al Hayani, The Department of Obstetrics and Gynecology, Faculty of Medicine, El Anbar University, Iraq

\section{Introduction}

POLYCYSTIC Ovary Syndrome (PCOS), is a common endocrine disorder, accounts for more than $10 \%$ of women of reproductive age PCOS isthe most common cause of anovulatory infertility and had a clinical symptoms include anovulation or oligoovulation, infertility, menstrual irregularity, polycysticovaries and hyperandrogenism [1,2].

PCOS is common among infertile Arabian femalepopulation and it is associated with significant elevations in markers of metabolic syndrome, insulin resistance and cardiovascular risks [3].

A meta-analysis demonstrated that vitamin D deficiency is common among women with PCOS, with $67-85 \%$ having serum concentrations of $25-$ hydroxyvitamin D (25OHD) <20ng/mL (or 50 nmol/L) [4].

Low vitamin D correlates with obesity and it is associated with increased insulin resistance, testosterone, and Dehydroepiandrosteronesulphate (DHEAS) levels [5].

Studies on vitamin D supplementation in PCOS have yielded mixed results, with some of them suggesting beneficial effects on glucose metabolism and insulin resistance, when vitamin $\mathrm{D}$ is given continuously at lower (<4000IU/day) doses as suggested in a recent meta-analysis, and improvements in menstrual frequency and hyperandrogenism, whereas others demonstrate no significant improvements [6-8].

So the aim of this study was to explore and compare the effects of vitamin D supplementation vs. placebo on ovulation in women with PCOS. 


\section{Patients and Methods}

After approval from the Institutional Ethics Committee, informed consent was obtained from each of the 400 women diagnosed with PCOS.

This double-blind, randomized, placebo-controlled study on reproductive-aged women (18-45 years) diagnosed with PCOS based on all three diagnostic criteria of the Rotterdam consensus were screened for vitamin D deficiency [31].

This study was conducted at Especial Clinic for Obstetric and Gynecology El Ramady, Iraq from 2017-2020.

Patients with age less than 18 or more than 40 years, diagnosed diabetes mellitus according to American Diabetes Association criteria: HBA1C $\geq 6.5 \%$, fasting plasmaglucose $\geq 126 \mathrm{mg} / \mathrm{dl}, 2-\mathrm{h}$ plasma glucose $\geq 200 \mathrm{mg} / \mathrm{dl}$ during an OGTT using a glucose load containing the equivalent of $75 \mathrm{~g}$ anhydrous glucose dissolved in wateror a random plasma glucose $\geq 200 \mathrm{mg} / \mathrm{dl}$ in a patient withclassic symptoms of hyperglycemia or hyperglycemiccrisis (American Diabetes Association, 2010), Anyendocrinological disorder, e.g. hypo/hyperthyroidism, Cushing's disease, any chronic medical disorder, e.g. renal disease, chronic liver disease, hypertension orautoimmune disorders, etc., Insulin sensitizing therapy, e.g. metformin or dipeptidyl peptidase 4 (DPP-4) inhibitors as sitagliptin, etc., Drugs affecting insulin resistance, e.g. steroids, women with other concomitant cause of infertility (e.g. abnormal semen analysis, tubal abnormalities, endometriosis, etc.) or pelvic pathology (e.g. endometrial polyp, hyperplasia, ovarian cyst, etc.), Vitamin D or calcium supplementation, oral contraceptivepill therapy or other hormonal treatment within last three cycles or mental condition rendering the patients unableto understand the nature, scope and possible consequences of the study were excluded from the current study.

Patients fulfilling the inclusion criteria were randomizedto two groups.

- Vitamin D Group: This group included 200 women with PCOS seeking fertility. This group was further stratified according to their vitamin D status into 2 subgroups by acutoff level of serum 25-hydroxyvitamin-D of 20ng/mL [8]: Vitamin $\mathrm{D}$ deficient subgroup included PCOS women with serum $25(\mathrm{OH}) \mathrm{D}<20 \mathrm{ng} / \mathrm{mL}$, who received supplemental vitamin D3 for 8 weeks, followed by induction of ovulation with clomiphene citrate.

Normal vitamin D subgroup included PCOSwomen with serum $25(\mathrm{OH}) \mathrm{D} \geq 20 \mathrm{ng} / \mathrm{mL}$, who start- ed induction of ovulation with clomiphenecitrate directly, without vitamin D supplementation.

- Control Group: This group included 200 women with PCOS seeking fertility. This group started induction of ovulation with clomiphene citrate without prior vitamin D supplementation.

\section{- Endpoint:}

Change vitamin D level, change in insulin resistance as measured by fasting glucose and fasting insulin ratio, change in testosterone level, and change in free androgen index.

Regimen: According to the Endocrine Societyguidelines, 6000IU of Vitamin D3 were given dailyto patients with Vitamin D deficiency for 12 weeks toachieve a serum level of $25(\mathrm{OH}) \mathrm{D}$ above $30 \mathrm{ng} / \mathrm{mL}$, followed by a maintenance dose of 2000 IU daily. Patients with BMI $>30 \mathrm{Kg} / \mathrm{m}^{2}$ were given a higherdosage of $10,000 \mathrm{IU}$ daily followed by a maintenance dose of $6,000 \mathrm{IU}$ daily.

All participants were advised to maintain their usual dietary and lifestylehabits during the study, for adjustment including smoking, sunlight exposure, and physical activity that could affect the levels of vitamin D and metabolic indices.

Data analysis:

Data was analyzed by using SPSS 24.0.

Quantitative data was presented as mean \pm standard deviation while qualitative data was presented as frequency and percentages.

Comparison between the two groups as regards quantitative variables was made by using paired $t$-test before and after intervention and ANOVA test was used between more than two groups.

Significant results were defined when the $p$ value was less than 0.05 .

\section{Results}

As in Fig. (1), this study included 420 women having PCOs, 20 of them were excluded. 200 of them allocated to control group. Among 200 women in vitamin D group, 160 women had vitamin D deficiency and the other 40 had normal vitamin D level.

In (Table 1), there were non-significant differences between the three study groups as regards age, BMI, type of infertility, duration of infertility and hirsutism score $(p>0.05)$.

In (Table 2), showed that FBS, fasting insulin and HOMA-IR were statistically significantly 
higher in the vitamin D deficient subgroup and the control group compared to the normal vitamin D subgroups; whereas no statistically significant differences were found between the vitamin D deficient subgroup and the control group. Nostatistically significant differences were found between the three groups in the various components of the lipid profile and hormonal profile.
In (Table 3), there were statistically significant differences between groups as regards FBS, fasting insulin, HOMA-IR, FAI, Testosterone, TC and LDL-C.

Tables $(4,5)$ showed statistically significant improvement in glycemic control, hormonal and lipid profile before and after vitamin D supplementation in vitamin D subgroups.

Table (1): Demographic and clinical data among three groups.

\begin{tabular}{|c|c|c|c|c|}
\hline \multirow[b]{2}{*}{ Baseline characteristics } & \multicolumn{2}{|c|}{ Vitamin D group } & \multirow{2}{*}{$\begin{array}{l}\text { Control group } \\
\mathrm{N}=200\end{array}$} & \multirow{2}{*}{$\begin{array}{c}p- \\
\text { value }\end{array}$} \\
\hline & $\begin{array}{l}\text { Deficient group } \\
\qquad \mathrm{N}=160\end{array}$ & $\begin{array}{l}\text { Normal group } \\
\mathrm{N}=40\end{array}$ & & \\
\hline $\begin{array}{l}\text { Age (years): } \\
\quad \text { Mean } \pm \text { SD }\end{array}$ & $29.97 \pm 4.13$ & $28.36 \pm 5.12$ & $30.09 \pm 4.1$ & $0.423 \bullet$ \\
\hline $\begin{array}{l}B M I K g / m^{2} \\
\quad \text { Mean } \pm \text { SD }\end{array}$ & $26.11 \pm 2.43$ & $25.73 \pm 3.21$ & $25.21 \pm 2.25$ & $0.173 \bullet$ \\
\hline $\begin{array}{l}\text { Type of infertility: } \\
\text { Primary } \\
\text { Secondary }\end{array}$ & $\begin{array}{l}110(68.75 \%) \\
50 \quad(31.25 \%)\end{array}$ & $\begin{array}{l}25(62.5 \%) \\
15(37.5 \%)\end{array}$ & $\begin{array}{l}155(77.5 \%) \\
45 \quad(22.5 \%)\end{array}$ & $0.615 \#$ \\
\hline $\begin{array}{l}\text { Duration of infertility: } \\
\text { Mean } \pm \text { SD }\end{array}$ & $6.4 \pm 1.3$ & $6 \pm 1.4$ & $6.2 \pm 1.5$ & $0.162 \bullet$ \\
\hline Menstrual irregularity & $166(83 \%)$ & $33(82.5 \%)$ & $162(81 \%)$ & $0.825 \#$ \\
\hline mFGhirsutism score & $10.3 \pm 3.8$ & $10.2 \pm 4.5$ & $10.2 \pm 5$ & $0.883 \bullet$ \\
\hline
\end{tabular}

$\because$ : ANOVA test used.

\#: Chi square test used.

$*$ : Statistical significant when $p$-value $<0.05$.

Table (2): Baseline measurements among three groups.

\begin{tabular}{|c|c|c|c|c|}
\hline \multirow{2}{*}{ Baseline characteristics } & \multicolumn{2}{|c|}{ Vitamin D group } & \multirow{2}{*}{$\begin{array}{l}\text { Control group } \\
\qquad \mathrm{N}=200\end{array}$} & \multirow{2}{*}{$\begin{array}{c}p- \\
\text { value }\end{array}$} \\
\hline & $\begin{array}{l}\text { Deficient group } \\
\quad \mathrm{N}=160\end{array}$ & $\begin{array}{c}\text { Normal group } \\
N=40\end{array}$ & & \\
\hline $25 O H D(n m o l / L):$ Mean \pm SD & $12.9 \pm 4.7$ & $28.3 \pm 1.5$ & $13.8 \pm 3.6$ & $0.001 * \bullet$ \\
\hline Fasting glucose $(m g / d L):$ Mean $\pm \mathrm{SD}$ & $98.2 \pm 4.13$ & $88.4 \pm 5.12$ & $97.9 \pm 4.1$ & $0.001 * \bullet$ \\
\hline Fasting insulin $(\mu I U / m L):$ Mean \pm SD & $28.42 \pm 3.2$ & $21.4 \pm 4.3$ & $28.21 \pm 3.1$ & $0.003 * \bullet$ \\
\hline HOMA-IR: Mean $\pm \mathrm{SD}$ & $3.4 \pm 0.6$ & $2.4 \pm 1.1$ & $3.5 \pm 1.2$ & $0.001 * \bullet$ \\
\hline$F A I:$ Mean $\pm \mathrm{SD}$ & $5.4 \pm 2.5$ & $4.9 \pm 1.8$ & $5.3 \pm 1.2$ & $0.073 \bullet$ \\
\hline Testosterone $(\mathrm{nmol} / \mathrm{L})$ : Mean $\pm \mathrm{SD}$ & $1.2 \pm 0.6$ & $1 \pm 0.9$ & $1.2 \pm 0.7$ & $0.263 \bullet$ \\
\hline$T C(m g / d L):$ Mean $\pm \mathrm{SD}$ & $155.2 \pm 21.2$ & $154 \pm 22.4$ & $154.3 \pm 22.5$ & $0.208 \bullet$ \\
\hline$T G(m g / d L):$ Mean $\pm \mathrm{SD}$ & $101.3 \pm 11.3$ & $106.6 \pm 14.4$ & $99.8 \pm 17.5$ & $0.162 \bullet$ \\
\hline$L D L-C(m g / d L):$ Mean $\pm \mathrm{SD}$ & $88.4 \pm 21.4$ & $86.4 \pm 19.2$ & $87.2 \pm 13.1$ & $0.311 \bullet$ \\
\hline$H D L-C(m g / d L):$ Mean \pm SD & $46.5 \pm 7.5$ & $47.3 \pm 6.4$ & $46.2 \pm 8.4$ & $0.243 \bullet$ \\
\hline \multicolumn{5}{|l|}{$\begin{array}{l}\bullet: \text { ANOVA test used. } \\
*: \text { Statistical significant when } p \text {-value }<0.05 \text {. }\end{array}$} \\
\hline $\begin{array}{ll}\text { Abbreviations: } \\
\text { 25OHD : } 25-\text {-hydroxyvitamin D. } \\
\text { HOMA-IR }: \text { Homeostatic Model Assessmen } \\
\text { TG } & : \text { Triglycerides. } \\
\text { TC } & : \text { Total Cholesterol. } \\
\text { LDL-C } & \text { : Low Density Lipoprotein Chole } \\
\text { HDL } & : \text { High Density Lipoprotein Chol } \\
\text { FAI } & \text { : Free Androgen Index. }\end{array}$ & f Insulin Resistance & & & \\
\hline
\end{tabular}


Table (3): Measurements after follow-up among three groups.

\begin{tabular}{|c|c|c|c|c|}
\hline \multirow{2}{*}{ Baseline characteristics } & \multicolumn{2}{|c|}{ Vitamin D group } & \multirow{2}{*}{$\begin{array}{c}\text { Control group } \\
\mathrm{N}=200\end{array}$} & \multirow{2}{*}{$\begin{array}{c}p- \\
\text { value }\end{array}$} \\
\hline & $\begin{array}{l}\text { Deficient group } \\
\quad \mathrm{N}=160\end{array}$ & $\begin{array}{c}\text { Normal group } \\
\quad N=40\end{array}$ & & \\
\hline $25 O H D(n m o l / L):$ Mean \pm SD & $25.6 \pm 2.5$ & $30 \pm 0$ & $18.4 \pm 2.8$ & $0.001 * \bullet$ \\
\hline Fasting glucose $(m g / d L):$ Mean \pm SD & $81.1 \pm 2.5$ & $79.9 \pm 2.3$ & $102.4 \pm 3.2$ & $0.001 * \bullet$ \\
\hline Fasting insulin $(\mu I U / m L)$ : Mean \pm SD & $20.3 \pm 2.1$ & $19.9 \pm 1.9$ & $29.6 \pm 1.5$ & $0.001 * \bullet$ \\
\hline HOMA-IR: Mean \pm SD & $2.3 \pm 0.8$ & $2.1 \pm 0.9$ & $3.7 \pm 1$ & $0.001 * \bullet$ \\
\hline FAI: Mean $\pm \mathrm{SD}$ & $4.7 \pm 0.9$ & $4.5 \pm 0.7$ & $5.5 \pm 1.3$ & $0.001 *_{\bullet}$ \\
\hline Testosterone $(\mathrm{nmol} / \mathrm{L})$ : Mean $\pm \mathrm{SD}$ & $1 \pm 0.4$ & $0.9 \pm 0.9$ & $1.3 \pm 0.9$ & $0.001 * \bullet$ \\
\hline$T C(m g / d L):$ Mean \pm SD & $150.6 \pm 23.1$ & $153.5 \pm 21.5$ & $155.3 \pm 22.9$ & $0.048 * \bullet$ \\
\hline$T G(m g / d L):$ Mean \pm SD & $100.2 \pm 10.5$ & $99.8 \pm 11.6$ & $110.4 \pm 12.4$ & $0.052 \bullet$ \\
\hline$L D L-C(m g / d L):$ Mean $\pm \mathrm{SD}$ & $84.5 \pm 19.3$ & $83.2 \pm 20.1$ & $88 \pm 12.2$ & $0.039 * \bullet$ \\
\hline$H D L-C(m g / d L):$ Mean \pm SD & $48 \pm 6.5$ & $48.3 \pm 5.4$ & $44.2 \pm 7.9$ & $0.061 \bullet$ \\
\hline
\end{tabular}

$\bullet:$ ANOVA test used.

*: Statistical significant when $p$-value $<0.05$.

Abbreviations:

25OHD : 25-hydroxyvitamin D.

HOMA-IR : Homeostatic Model Assessment of Insulin Resistance. LDL-C : Low Density Lipoprotein Cholesterol.

TG : Triglycerides. $\quad$ HDL : High Density Lipoprotein Cholesterol.

TC : Total Cholesterol. FAI : Free Androgen Index.

Table (4): Measurements before and after follow-up among Vitamin D deficient group.

\begin{tabular}{|c|c|c|c|}
\hline \multirow{2}{*}{$\begin{array}{l}\text { Baseline } \\
\text { characteristics }\end{array}$} & \multicolumn{2}{|c|}{$\begin{array}{l}\text { Deficient group } \\
\quad \mathrm{N}=160\end{array}$} & \multirow{2}{*}{$\begin{array}{c}p- \\
\text { value }\end{array}$} \\
\hline & Before & After & \\
\hline 25OHD (nmol/L) & $12.9 \pm 4.7$ & $25.6 \pm 2.5$ & $0.001 * \bullet$ \\
\hline Fasting glucose (mg/dL) & $98.2 \pm 4.13$ & $81.1 \pm 2.5$ & $0.001 *_{\bullet}$ \\
\hline Fasting insulin $(\mu \mathrm{IU} / \mathrm{mL})$ & $28.42 \pm 3.2$ & $20.3 \pm 2.1$ & $0.001 *_{\bullet}$ \\
\hline HOMA-IR & $3.4 \pm 0.6$ & $2.3 \pm 0.8$ & $0.001 * \bullet$ \\
\hline FAI & $5.4 \pm 2.5$ & $4.7 \pm 0.9$ & $0.001 *_{\bullet}$ \\
\hline Testosterone $(\mathrm{nmol} / \mathrm{L})$ & $1.2 \pm 0.6$ & $1 \pm 0.4$ & $0.001 * \bullet$ \\
\hline $\mathrm{TC}(\mathrm{mg} / \mathrm{dL})$ & $155.2 \pm 21.2$ & $150.6 \pm 23.1$ & $0.022 * \bullet$ \\
\hline $\mathrm{TG}(\mathrm{mg} / \mathrm{dL})$ & $101.3 \pm 11.3$ & $100.2 \pm 10.5$ & $0.037 * \bullet$ \\
\hline LDL-C (mg/dL) & $88.4 \pm 21.4$ & $84.5 \pm 19.3$ & $0.020 * \bullet$ \\
\hline $\mathrm{HDL}-\mathrm{C}(\mathrm{mg} / \mathrm{dL})$ & $46.5 \pm 7.5$ & $48 \pm 6.5$ & $0.035^{*} \bullet$ \\
\hline
\end{tabular}

•: Paired $t$-test used. *: Statistical significant when $p$-value $<0.05$. Abbreviations:

25OHD : 25-hydroxyvitamin D. TG: Triglycerides.

HOMA-IR: Homeostatic Model Assessment of Insulin Resistance.

LDL-C : Low Density Lipoprotein Cholesterol.

HDL : High Density Lipoprotein Cholesterol.

FAI: Free Androgen Index. $\quad$ TC: Total Cholesterol.
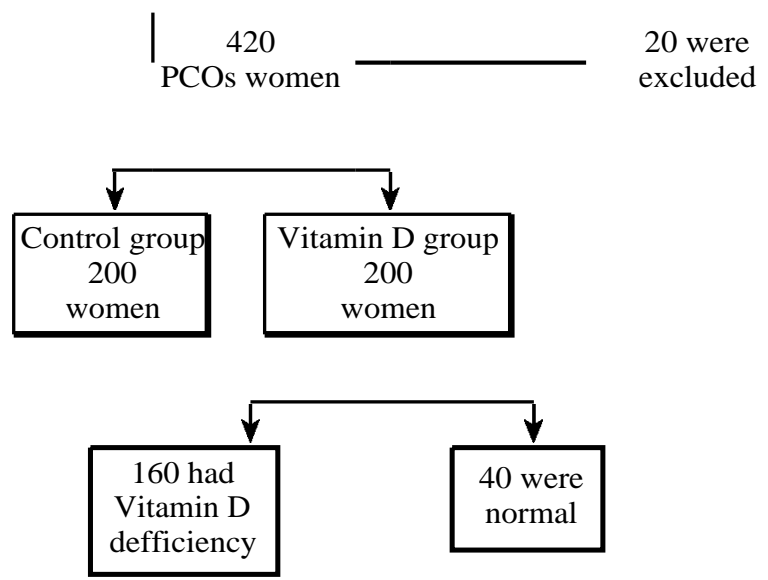

Fig. (1): Flow chart of patients allocation.
Table (5): Measurements before and after follow-up among Vitamin D normal group.

\begin{tabular}{llll}
\hline \multirow{2}{*}{$\begin{array}{l}\text { Baseline } \\
\text { characteristics }\end{array}$} & \multicolumn{2}{c}{$\begin{array}{c}\text { Normal group } \\
\mathrm{N}=40\end{array}$} & $\begin{array}{c}p- \\
\text { value }\end{array}$ \\
\cline { 2 - 3 } & Before & After & \\
\hline 25OHD (nmol/L) & $28.3 \pm 1.5$ & $30 \pm 0$ & $0.032^{* \bullet}$ \\
Fasting glucose $(\mathrm{mg} / \mathrm{dL})$ & $88.4 \pm 5.12$ & $79.9 \pm 2.3$ & $0.041^{*}$ \\
Fasting insulin $(\mu \mathrm{IU} / \mathrm{mL})$ & $21.4 \pm 4.3$ & $19.9 \pm 1.9$ & $0.047^{*}$ \\
HOMA-IR & $2.4 \pm 1.1$ & $2.1 \pm 0.9$ & $0.039^{*}$ \\
FAI & $4.9 \pm 1.8$ & $4.5 \pm 0.7$ & $0.033^{*}$ \\
Testosterone (nmol/L) & $1 \pm 0.9$ & $0.9 \pm 0.9$ & $0.048^{*}$ \\
TC (mg/dL) & $154 \pm 22.4$ & $153.5 \pm 21.5$ & $0.162^{\bullet}$ \\
TG $(\mathrm{mg} / \mathrm{dL})$ & $106.6 \pm 14.4$ & $99.8 \pm 11.6$ & $0.042^{*}$ \\
LDL-C (mg/dL) & $88.4 \pm 21.4$ & $83.2 \pm 20.1$ & $0.051^{\bullet}$ \\
HDL-C (mg/dL) & $47.3 \pm 6.4$ & $48.3 \pm 5.4$ & $0.036^{*}$ \\
\hline
\end{tabular}

$\because$ Paired $t$-test used. *: Statistical significant when $p$-value $<0.05$. Abbreviations:

25OHD : 25-hydroxyvitamin D. TG: Triglycerides.

HOMA-IR: Homeostatic Model Assessment of Insulin Resistance.

LDL-C : Low Density Lipoprotein Cholesterol.

HDL : High Density Lipoprotein Cholesterol.

FAI: Free Androgen Index. $\quad$ TC: Total Cholesterol.

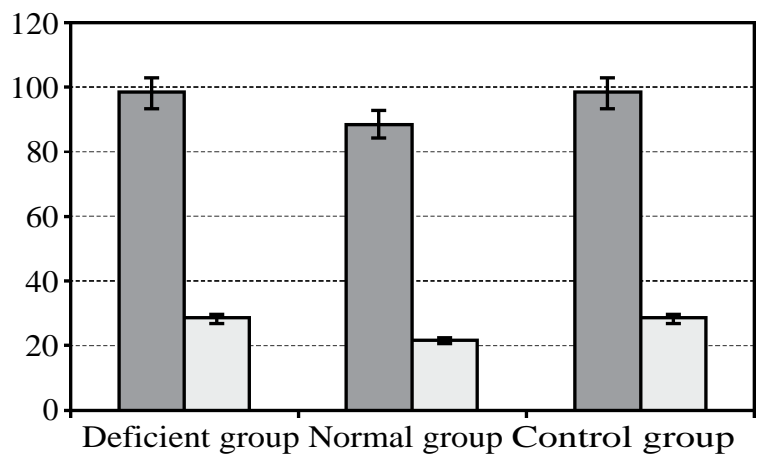

Fasting glucose

Fasting insulin

Fig. (2): Comparison of fasting bloob glucose level and insulin amond study groups. 


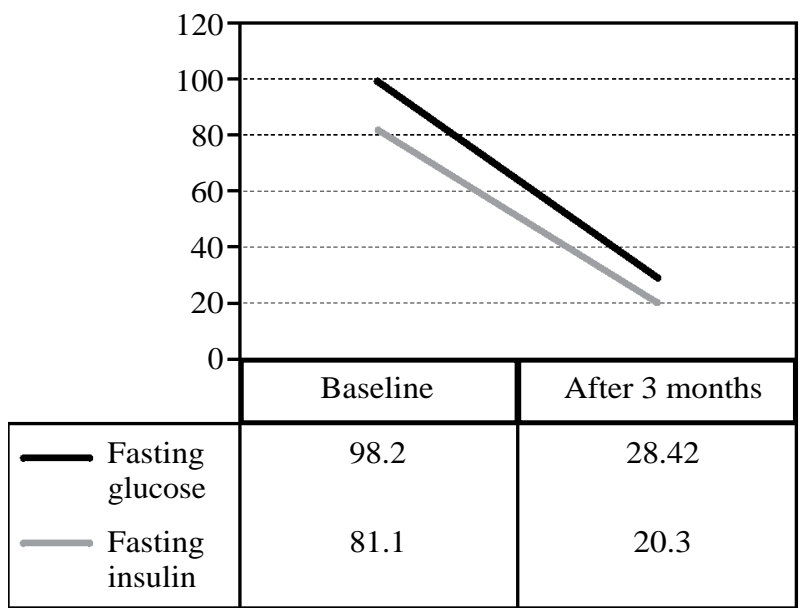

Fig. (3): Comparison of fasting bloob glucose level and insulin among vitamin $\mathrm{D}$ deficient group.

\section{Discussion}

A growing body of literature suggests the mechanisticimplications of Vitamin D deficiency for insulin resistance, inflammation, dyslipidemia and obesity, i.e. clinical and metabolic phenomena commonly encountered in PCOS [9].

According to the results of our study, Vitamin $\mathrm{D}$ deficient PCOS women tended to have higher degree of insulin resistance. Fasting glucose was statistically significantly higher in the Vitamin D deficient subgroup compared to the normal Vitamin D subgroup and the control group. Fasting insulin level was statistically significantly higher in the Vitamin D deficient subgroup and the controlgroup compared to the normal Vitamin D subgroup.

Consequently, HOMA2-IR was statistically significantly higher in the Vitamin D deficient subgroup and the control group compared to the normal Vitamin D subgroup.

Following Vitamin D supplementation in Vitamin D deficient-PCOS, glycemic profile showed adecline in tendency to insulin resistance noted before Vitamin D3 supplementation. Fasting glucose levels statistically significantly declined following Vitamin D3 supplementation compared to the pre-supplementation levels and the control PCOS women, to reach a level that didn't differ significantly compared to the normal 25OHD PCOS women. Fasting insulin levels also declined significantly in Vitamin D deficient-PCOS women following Vitamin D3 supplementation, achieving a level that is statistically significantly lower when compared to both the normal 25OHD and control PCOS women.

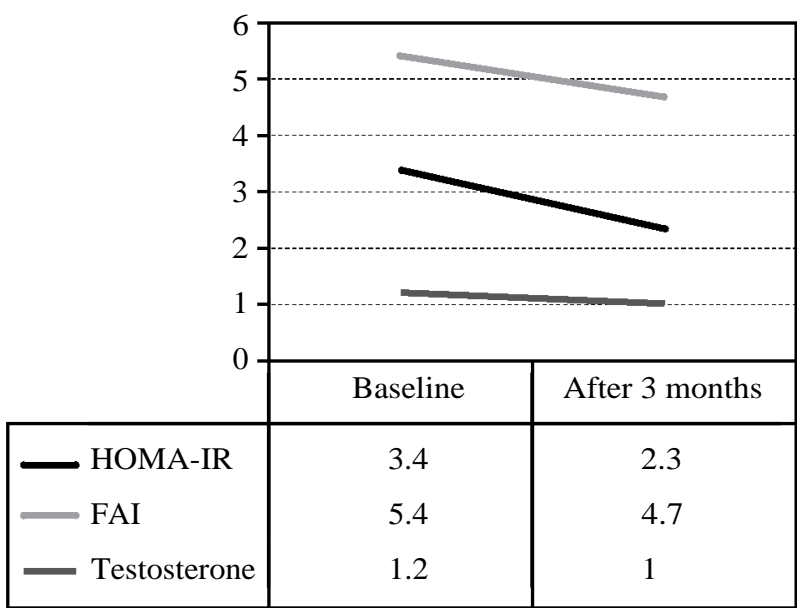

Fig. (4): Comparison of HOMA-IR, FAI and testosterone among Vitamin D deficient group.

After vitamin supplementation in Vitamin Ddeficient PCOS women, HOMA2-IR declined significantly to a value that is significantly lower than that estimated in the normal 25OHD and control groups.

At least in theory, Vitamin D has an established regulatory effect on the intracellular and extracellular calcium levels that is essential for insulin-mediated intracellular processes, and may have impact on insulin secretion and insulin sensitivity [10].

Another hypothesis involves the stimulatory effect of Vitamin D on the expression of insulin receptors. In addition, Vitamin D affects the immune system and can cause a higher inflammatory response associated with insulin resistance. Also, Vitamin D canaffect insulin resistance through the renin-angiotensinaldosterone system [11-13].

Wehr et al., demonstrated that Vitamin D treatment at adosage of $20000 \mathrm{IU}$ weekly for 24 weeks improved glucosemetabolism and menstrual frequency in PCOS women [14].

On the contrary, Ardabili et al., [15] observed no significant change in fasting serum insulin and glucose concentrations, insulin sensitivity and homeostasis mode lassessment of insulin resistance following supplementation with 50,000IU Vitamin D3 for 2 months among patients with PCOS. However, a major drawback of the latter study is the relatively low dose of Vitamin D3 treatment which is much lower than the current proposed guideline.

According to the assessment of hormonal profileaberrations in PCOS women in our study, no statistically significant differences were found between the Vitamin D deficient-PCOS women 
and those with normal Vitamin D status regarding gonadotropic and androgenic hormonal profiles. This might be explained by the clinical and biochemical nature of the diagnostic criteria of PCOS that identify a common phenotypic and/or hormonal abnormality, rather than a specificmolecular defect. Following Vitamin D3 supplementation in Vitamin D deficient-PCOS women, both LH and E2 levels significantly declined; whereas FSH levels significantly increased. In the same context, after Vitamin D3 supplementation in vitamin D deficient-PCOS women, marked improvement in the androgenic hormonal profile was noted, evidenced by statistically significant reductionin serum total testosterone level and increase in SHBG level yielding an overall decline in free androgen index.

\section{Conclusion:}

The findings of our study suggest that Vitamin $\mathrm{D}$ seems to be a contributing etiopathogenic factor in anovulatory, metabolic andhormonal aberrations in women with PCOS that might have a potential adjuvant role to standard induction of ovulation regimen but larger multicenter studies is recommended to establish the long-term outcomes.

\section{References}

1- ANAGNOSTIS P., KARRAS S. and GOULIS D.G.: Vitamin D in human reproduction: A narrative review. Int. J. Clin. Pract., 67 (3): 225-35, 2013.

2- GUO Q., KUMAR T.R., WOODRUFF T., HADSELL L.A., DeMAYO F.J. and MATZUK M.M.: Overexpression of Mouse Follistatin Causes Reproductive Defects in Transgenic Mice. Mol. Endocrinol., 12 (1): 96-106, 1998.

3- LEGRO R.S., FINEGOOD D. and DUNAIF A.: A fasting glucose to insulin ratio is a useful measure of insulin sensitivity in women with polycysticovary syndrome. J. Clin. Endocrinol. Metab., 83 (8): 2694-8, 1998.

4- MATTU H.S. and RANDEVA H.S.: Role of adipokines in cardiovascular disease. J. Endocrinol., 216 (1): T1736, 2013.

5- SANG Q., ZHANG S., ZOU S., WANG H., FENG R., LI Q., JIN L., HE L., XING Q. and WANG L.: Quantitative analysis of follistatin (FST) promotermethylation in peripheral blood of patients with polycystic ovary syndrome. Reprod Biomed. On., 26 (2): 157-63, 2013.

6- THOMSON R.L., SPEDDING S. and BUCKLEY J.D.: Vitamin D in the Aetiology and Management of Polycystic Ovary Syndrome. Clin. Endocrinol., 77 (3): 343-50, 2012.

7- WANG Y., ZHU J. and DeLUCA H.F.: Where is the Vitamin D receptor? Arch. Biochem. Biophys., 523 (1): 123-33, 2012

8- HOLICK M.F., BINKLEY N.C., BISCHOFF-FERRARI H.A., GORDON C.M., HANLEY D.A., HEANEY R.P., MURAD M.H. and WEAVER C.M.: Endocrine Society. Evaluation, treatment, and prevention of vitamin D deficiency: An Endocrine Society clinical practice guideline. J. Clin. Endocrinol. Metab., 96 (7): 1911-30, 2011.

9- KRUL-POEL Y.H., SNACKEY C., LOUWERS Y., LIPS P., LAMBALK C.B., LAVEN J.S. and SIMSEK S.: The role of vitamin $\mathrm{D}$ in metabolic disturbances in polycystic ovary syndrome: A systematic review. Eur. J. Endocrinol., 169 (6): 853-65, 2013.

10- PITTAS A.G., LAU J., HU F.B. and DAWSON-HUGHES B.: The role of vitamin $\mathrm{D}$ and calcium in type 2 diabetes. A systematic review and meta-analysis. J. Clin. Endocrinol. Metab., 92: 2017-29, 2007.

11- MAESTRO B., MOLERO S., BAJO S., DAVILA N. and CALLE C.: Transcriptional activation of the humaninsulin receptor gene by 1,25 -dihydroxyvitamin $\mathrm{D}(3)$. Cell Biochem. Funct., 20: 227-32, 2002.

12- HAHN S., HASELHORST U., TAN S., QUADBECK B., SCHMIDT M., ROESLER S., KIMMIG R., MANN K. and JANSSEN O.E.: Low serum 25-hydroxyvitamin D concentrations are associated with insulin resistance and obesity in women with polycysticovary syndrome. Exp. Clin. Endocrinol. Diabetes, 114: 577-83, 2006.

13- RAMMOS G., TSEKE P. and ZIAKKA S.: Vitamin D, the renin-angiotensin system, and insulin resistance. Int. Urol. Nephrol., 40: 419-26, 2008.

14- WEHR E., PILZ S., BOEHM B.O., MARZ W. and OBERMAYER PIETSCH B.: Association of vitamin Dstatus with serum androgen levels in men. Clin. Endocrinol. (Oxf)., 73: 243-8, 2010.

15- ARDABILI H.R., GARGARI B.P. and FARZADI L.: Vitamin D supplementation has no effect on insulinresistance assessment in women with polycysticovary syndrome and vitamin D deficiency. Nutr. Res., 32: 195-201, 2012. 


\section{تآثير مكملات فيتامين د على التبويض التيل

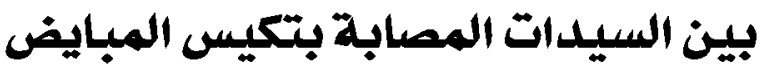

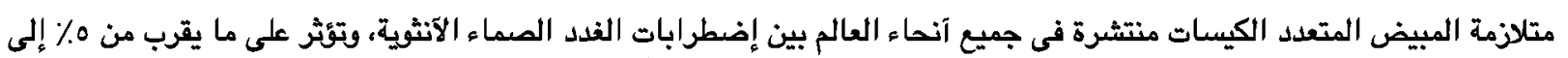

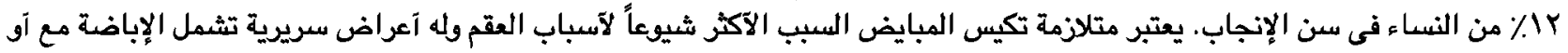

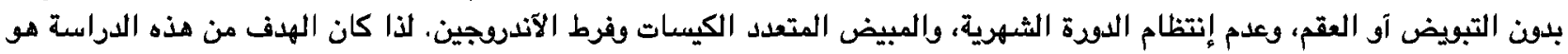

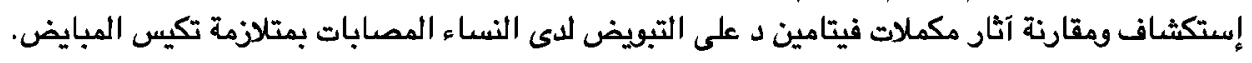

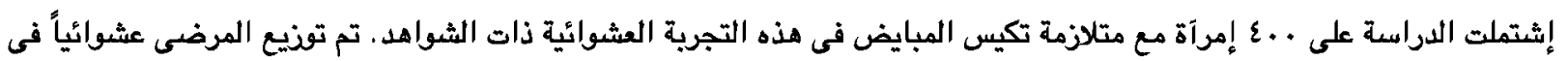

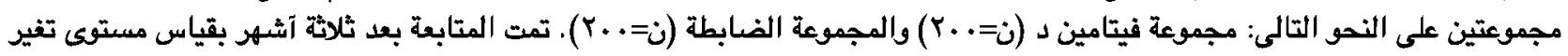

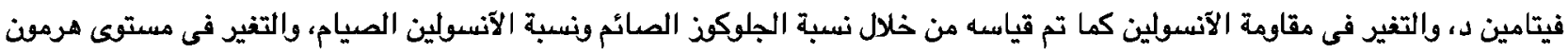
التستوستيرون، والتغير فى مؤشر الآندرجين.

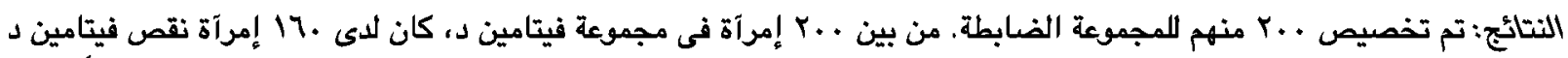

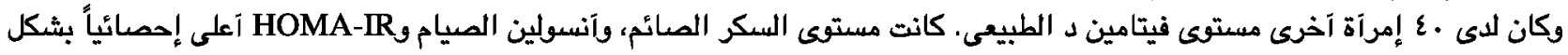

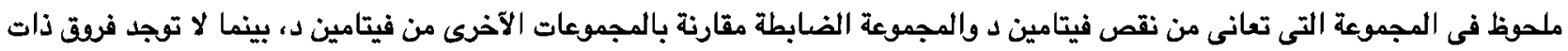

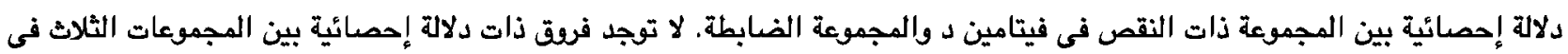
المكونات المختلة لصورة دهون الدم والهرمونات.

الخلاصة: إستتنجنا آن فيتامين د ييدو آنه عامل مُسبب للمرض فى مشاكل التبويض والهرمونات لدى النساء المصابات بمتلازمة تكيس

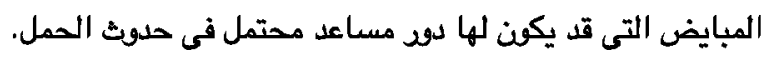

